\title{
СЕМАНТИКО-СТРУКТУРНА ХАРАКТЕРИСТИКА ВІДАНТРОПОНІМНИХ НАЗВ ПОСЕЛЕНЬ ЗАПОРІЗЬКОГО КРАЮ
}

\author{
Ільченко I. I., Ткаченко Н. В.
}

\section{ВСТУП}

Відантропонімні ойконіми - це назви населених пунктів, походження яких пов'язане з іменами, прізвищами, прізвиськами їхніх власників або мешканців. Мовознавці стверджують, що частіше на базі власних імен формуються топоніми. Власні назви ж, утворені на базі топонімів, трапляються рідше, хоча на початковому етапі такий шлях творення в українській мові належав до продуктивних. Якщо брати історичну послідовність виникнення власних назв, то спочатку творяться антропоніми, потім - гідроніми, уже пізніше - ойконіми, тобто полярними позиціями у співвідношенні власних назв виступають антропоніми й ойконіми ${ }^{1}$.

Функціонування назв відантропонімного походження, здавалося б, можливе лише в одному населеному пункті, однак це не так, бо повторюються не тільки однакові імена та їх варіанти, а й прізвища чи прізвиська у складі ойконімів Запорізького краю, про що свідчитимуть приведені нижче приклади. Із цією метою пропонуємо розглянути ойконіми, що утворились від чоловічих і жіночих імен.

Кінець XVII - початок XVIII ст. щодо розвитку української мови $\epsilon$ важливим із погляду функціонального впливу на нього іншомовної топонімії. Характерною межею іншомовних географічних назв у цей період $\epsilon$ їхня різнорідність стосовно мови-джерела, а також їхня масовість у мові-приймачі. Це пояснюється характером мовного впливу й екстралінгвістичною ситуацією в Україні XVII - XVIII ст. Звичайно, у XVIII ст. найбільше нових думок, фактів, спостережень виявляється в писемних ділових пам'ятках та документах ${ }^{2}$.

Основна причина запозичення іншомовної топонімії на екстралінгвістичному рівні полягає в необхідності найменування

1 Лобода В. Вплив антропонімії і гідронімії на творення сучасної ойконімії Північного Причорномор'я. Питання ономастики Південної України : матеріали V Республіканської ономастичної конференції. Київ, 1974. С. 107-112.

2 Лучик В. Етимологічний словник топонімів України. Київ : ВЦ «Академія», 2014. C. 29-30. 
нового явища та іiї входження у словниковий ужиток мови-реципієнта. У цьому разі маємо на увазі назви географічних об'єктів, які ввійшли в мову й історію та закріпились у них через документи, грамоти, універсали, акти сотенних канцелярій та міських ратуш XVII - XVIII ст. Тривалість їх уживання носіями близьких за природою слов'янських мов була зумовлена передусім зовнішніми причинами:

- тісними політичними, соціально-економічними та культурними зв’язками України із країнами Західної Свропи;

- соціально-економічними та політичними змінами у внутрішньому житті країн, що приймають іншомовну топонімію;

- роллю країни та мови, з якої відбувається запозичення онімів, на політичній арені світу;

- впливом латинської та польської мов на освоєння іншомовної топонімії українською й російською мовами як мов-посередників;

- відсутністю нації та державності ${ }^{3}$.

Внутрішньосистемні новоутворення різноманітні як за своєю природою, так і за характером виконуваних ними функцій. Автономні процеси, які відбуваються всередині лексичної підсистеми мови, опосередковані зовнішніми стимулами. Останне приводить у дію мовний механізм, який прагне дати вже відомому поняттю зручне для такого стану мовної системи значення, відповідне тим або іншим тенденціям у сучасному розвитку. Отже, зовнішні стимули нібито «оформлюють» внутрішньомовні чинники ${ }^{4}$.

Як відомо, ойконіми відантропонімного походження найчисельніші за своїм складом у багатьох мовах і з'явились внаслідок загального суспільного розвитку, соціальної диференціації населення й інших причин. Під час аналізу першовитоків найменувань виходять 3 думки, що в топонімії переважають назви, започатковані від прізвищ або особових імен засновників поселень, першопоселенців, власників населених пунктів. Відантропонімний підхід до тлумачення ойконімів надзвичайно корисний і плідний, дає правильну етимологію величезної кількості географічних назв. Проте співвідношення відантропонімних твірних основ у топонімії різних регіонів і різних мов вражаюче 5 .

${ }^{3}$ Беценко Т. Етюди 3 топонімії Сумщини. Походження географічних найменувань. Суми : Собор, 2001. С. 55-56.

${ }^{4}$ Воробйова Л. Лінгвістичні й екстралінгвістичні умови формування українського національного топонімічного фонду й процесу запозичення іншомовної топонімії наприкінці XVII - початку XVIII ст. Мовознавчий вісник. 2010. Вип. 11. C. 115-118. URL: http://nbuv.gov.ua/UJRN/Mv_2010_11_27.

5 Скляренко О.М. Деякі зауваження щодо топонімів відантропонімного походження (типологічний аспект). Слов'янський збірник : збірник наукових праць. Одеса : Одеський національний університет імені I.I. Мечникова, 2012. Вип. 16. C. 221 . 
Ойконімізація антропонімів виключно трансформаційним, конверсійним шляхом, без залучення інших топонімотворчих засобів, трапляється не дуже часто. Антропонімний підхід до аналізу ойконімів має і свою негативну сторону: дослідники намагаються передусім дати відантропонімну етимологію назв, що розглядаються, і лише потім звертаються до інших інтерпретацій. Цей підхід отримує i методологічну підтримку. На думку деяких топонімістів, з того факту, що поселення створюються людьми і для людей, випливає, що саме антропологічний чинник повинен братися до уваги в першу чергу, навіть коли основа ойконіма називає інші, дуже близькі й відомі носіям мови поняття чи реалії.

Антропоніми, які $\epsilon$ етимонами ойконімів Запорізького краю, поділяються на імена грецького, латинського, єврейського i давньоруського походження. Кожна підгрупа репрезентується різною кількістю прикладів у топонімії досліджуваного регіону.

\section{1. Ойконіми, що утворені від чоловічих та жіночих імен грецького та латинського походження}

Для відантропонімних ойконімів Запорізького краю характерна наявність специфічних суфіксальних топоформантів, які вказують на приналежність об'єкта певній особі. Важливість такої групи назв полягає у тому, що часто топоніми зберігають антропонімічну спадщину не зафіксовану, або не впорядковану в жодних документах i словниках.

На терені Запорізької області зафіксовано велику кількість ойконімів із формантами -ів-, -ськ-, зі складним формантом -івк(a) та його варіантом -ївк(a).

М. Кордуба у праці «Що кажуть нам назви осель?» зауважує, що деривати із суфіксом -івк(a) уперше були засвідчені в документах XIV cr ${ }^{7}$. На підтвердження цієї думки додамо, що в назвах новозаснованих поселень та в перейменуваннях населених пунктів часто спостерігається активне іiї використання навіть у XX ст.

Майже в усіх випадках ойконіми на -івк(a), -ївк(a) відантропонімні, a їх основи часто вказують на ім'я або прізвище першопоселенця чи власника двору, садиби.

6 Скляренко О.М. Деякі зауваження щодо топонімів відантропонімного походження (типологічний аспект). Слов'янський збірник : збірник наукових праць. Одеса : Одеський національний університет імені I.I. Мечникова, 2012. Вип. 16. С. 222.

Кордуба М.М. Що кажуть нам назви осель? Наша Батьківщчина. Львів, 1938. № 2. C. 31-37. 
Кількісно значну групу сучасних топооб'єктів Запорізької області складають іменні ойконіми чоловічого та жіночого роду грецького походження. Від таких імен були утворені зазначені відантропонімні ойконіми:

- Купріян (Купріянівка, Мала Купріянівка);

- Георгій (Георгївське);

- Микола (Миколаївка, Новомиколаївка, Микільське);

- Кирило (Кирилівка);

- Петро (Петрівка, Новопетрівка, Святопетрівка, Петрівське);

- Олександр (Олександрівка, Новоолександрівка);

- Степан (Степанівка Друга);

- Федорівка (Федорівка, Новофедорівка);

- Андрій (Андріївка);

- Василь (Нововасилівка, Васильківське);

- Радивон (Радивонівка);

- Софія (Софіїкка, Новософївка);

- Катерина (Малокатеринівка).

Купріянівка - село у Вільнянському районі Запорізької області. Село утворилось в першій половині XIX ст. у володіннях графа Крейда та було засноване німцями-переселенцями. Перша назва села Крейцерове, у 1844 р. село дістало нову назву - Купріянівка. На території села також селилися вихідці 3 Полтавської губернії. У 1917 р. воно ввійшло до складу Української Народної Республіки (далі - УНР). Унаслідок поразки Перших визвольних змагань село надовго окуповане більшовицькими загарбниками. У 1932-1933 рр. селяни пережили сталінський геноцид. Із 24 серпня 1991 р. село стало належати незалежній Україні ${ }^{8}$. Ойконім Купріянівка створено шляхом топонімійної деривації за допомогою топонімного афікса -івк(a).

Мала Купріянівка - село у Вільнянському районі Запорізької області. Село утворилося в 1930-х рр., три роки потому пережило комуністичний геноцид. Із 24 серпня 1991 р. село у складі незалежної України. До 19 травня 2016 р. село мало назву Кіровське, а потім за постановою Верховної Ради України воно отримало назву Мала Купріянівка ${ }^{9}$.

Георгї̈вське - утворилось як хутір у 1921 р. У 1932-1933 рр. селяни пережили сталінський геноцид, а із 24 серпня 1991 р. село входить до складу незалежної України ${ }^{10}$. Назва села утворена від імені Георгій із використанням суфіксів -iв- і -cbк-.

\footnotetext{
${ }^{8}$ Фоменко В. Звідки ця назва? Дніпропетровськ : Промінь, 1969. С. 51.

${ }^{9}$ Там само. С. 51 .

${ }^{10}$ Там само. С. 29.
} 
Миколаївка - село Приазовського району, розташоване на лівому березі р. Корсак, засноване на місці ногайського аулу Канлигари болгарськими переселенцями із с. Карагача (Нагірного). Першу назву села російською мовою Николаевка або Первониколаевка наприкінці $\mathrm{XX}$ ст. було передано українською мовою без урахування національної ідентифікації як Миколаївка (акт перейменування) ${ }^{11}$. Ойконім Миколаївка утворено від імені Николай (доцільно - Ніколаївка) шляхом топонімійної деривації з використанням топонімного афікса -івк(a).

Новомиколаївка - селище міського типу Запорізької області, райцентр. Селище засноване в останній чверті XVIII ст. державними селянами, вихідцями із селища Кочережки Павлоградського повіту Катеринославської губернії, як селище Кочережки. 31813 р. населений пункт став називатися Новомиколаӥвкою ${ }^{12}$.

Микільське - утворилось на початку XIX ст. на землях поміщика Миколи Івановича Рудя. У 1917 р. село входить до складу Української Народної Республіки. Унаслідок поразки Перших визвольних змагань село надовго окуповане більшовицькими загарбниками. У 1923 р. була організована Микільська сільська рада, на початку 1930-х рр. - колгосп «Шлях майбутнього», який у повоєнні роки увійшов до складу колгоспу ім. Щорса. У 1932-1933 pp. село пережило сталінський геноцид. Із 24 серпня 1991 р. село входить до складу незалежної України ${ }^{13}$. Ойконім Микільське складається 3 похідної основи микільськ-, де виокремлюються корінь микіль- і суфікс -ськ-.

Кирилівка - селище міського типу, розташоване в Якимівському районі Запорізької області ${ }^{14}$. Воно було засноване в $1805 \mathrm{p}^{15}$., попередня назва - Горіле. Ойконім сформувався за допомогою суфікса -івк(a) у релятивно-посесійній функції від імені одного 3 першопоселенців Кирила Капустіна.

Петрівка - село, розташоване у Приморському районі, засноване на місці ногайського аулу Машкир бессарабськими болгарами із с. Карагача (Нагірне). Першу назву села російською мовою Петровская

11 Мриглод М. Становлення і розвиток моделей ойконімів Правобережної України із християнськими іменами в основах : автореф. дис. ... канд. філол. наук: 10.02.01. Івано-Франківськ, 2002. С. 15.

${ }^{12}$ Бажан О. Новомиколаївка. Енщиклопедія історії України / редкол. : В. Смолій (гол.) та ін. Київ : Наукова думка, 2010. T. 7. C. 476. URL: http://www.history.org.ua/ ?termin=Novomykolaivka.

${ }_{13}$ Фоменко В. Звідки ця назва? Дніпропетровськ : Промінь, 1969. С. 51

14 Українська мова : енциклопедія / НАН України, Ін-т мовознав. ім. О.О. Потебні, Ін-т укр. мови ; за ред. В. Русанівського та ін. 2-ге вид., випр. і допов. Київ : Вид-во «Українська енциклопедія» ім. М.П. Бажана, 2004. С. 183.

${ }^{15}$ Географічна енциклопедія України : у 3-х т. / редкол. : О. Маринич (відп. ред.) та ін. Київ : УРЕ ім. М.П. Бажана, 1989. Т. 1. С. 151. 
невдовзі було трансформовано на Петровка, а наприкінці XX ст. відповідно передано українською мовою як Петрівка (ураховуючи чергування [о] 3 [i]). Очевидно, що відбулося перейменування ${ }^{16}$.

Новопетрівка - одне з найстаріших поселень Запорізької області. Історія села починається в 1770 р., коли на цьому місці була побудована фортеця (одна з фортець Дніпровської укріпленої лінії). Спочатку фортеця і поселення називалися Петровським посадом. У 1829 р. посад перейменували на станицю, вона стала центром Азовського козачого війська, утвореного козаками Задунайської Січі. У 1865 p. Азовське козаче військо було ліквідовано, і станиця перетворилася на звичайне село. На відміну від села Cтаропетрівка, яке знаходилося поблизу і виникло набагато пізніше, його назвали Новопетрівка ${ }^{17}$. Ойконім Новопетрівка складається із 2-х основ (непохідна ново- і похідна петрівк-) та сполучного голосного -о-. У похідній основі петрівк- виділяються корінь -петр- і суфікс -івк(а).

Святопетрівка - село в Гуляйпільському районі Запорізької області. Село розташоване за 2,5 км від лівого берега річки Гайчур, на відстані 1,5 км від села Криничне та за 2,5 км від села Зелене. По селу протікає пересихаючий струмок із загатою. Поруч проходить залізниця, станція Гуляйполе за $4 \mathrm{~km}^{18}$. Ойконім складається із 2-х основ, непохідної свято- і похідної петрівк-, сполучного голосного -о-.

Петрівське - село, розташоване за 2,5 кілометри від села Скелювате та за 3 км від сіл Любимівка, Біляївка і Новогупалівка. У XIX ст. в цій місцевості мешкали німці-переселенці. Наприкінці XIX ст. тут знаходився маєток Генріха Нейфельда, якому належав завод сільськогосподарських машин у Софіївці. У 20-х рp. XIX ст. сюди прибули переселенці із Західної України, якими було засноване село Петрівське. У період 1932-1933 рр. місцеві селяни пережили сталінський геноцид ${ }^{19}$. Ойконім складається 3 похідної основи петрівськ-, де виокремлюються корінь петр-, суфікси -ів- та -ськ-.

Олександрівка - село, розташоване в Якимівському районі, на березі p. Малий Утлюг, засноване бессарабськими болгарами та гагаузами із c. Табак. Першу назву села російською мовою Александровка наприкінці XX ст. було передано українською мовою як Олександрівка

16 Мриглод М. Становлення і розвиток моделей ойконімів Правобережної України із християнськими іменами в основах : автореф. дис. ... канд. філол. наук: 10.02.01. Івано-Франківськ, 2002. С. 15.

${ }^{17}$ Там само. С. 16.

${ }^{18}$ Історія міст і сіл Української РСР : у 26-ти т. Запорізька область / редкол. т. :

В. Петрикін (гол.) та ін. Київ : Головна редакція УРЕ, 1970. Т. 9. С. 296.

${ }^{19}$ Фоменко В. Звідки ця назва? Дніпропетровськ : Промінь, 1969. С. 77. 
без урахування національної ідентифікації ${ }^{20}$. Даний ойконім було створено шляхом топонімійної деривації від відповідного імені за допомогою топонімного афікса -івк(a).

Новоолександрівка - село в Запорізькому районі Запорізької області. Село було засноване німцями-колоністами, представниками лютеранства - протестантської течії у християнстві, у 1879 р. як село Поди. У 1914 р. німці-поселенці перейменовали село на Олександрталь. У 1932 р. воно отримало нинішню назву Новоолександрівка. На околицях села знаходяться кургани, які відносяться до поселення епохи бронзи ${ }^{21}$. Ойконім Новоолександрівка складається із 2-х основ (непохідна ново- і похідна олександрівк-) та сполучного голосного -о-. У похідній основі олександрівк- виділяються корінь -олександр- та суфікс -івк(а).

Степанівка Друга - село, розташоване у Приазовському районі, на березі р. Корсак, засноване на місці ногайського аулу Сарлар бессарабськими болгарами, що переселилися із с. Чешмаваруіта (Криничне) та м. Болграда. Першу назву села російською мовою Степановка в радянський період було трансформовано на Степановка Вторая (у Приазовському районі Запорізької області виявилося два села 3 однією назвою) $)^{22}$. Наприкінці XX ст. це найменування було передане українською мовою як Степанівка Друга. Очевидно, що ойконім Степанівка утворено шляхом топонімійної деривації від імені Степан за допомогою топонімного афікса -івк(a).

Федорівка - село, розташоване у Приазовському районі, на березі р. Апанли, засноване на місці ногайського аулу Кизильдин-Оглу бессарабськими болгарами с. Новопокровки. Першу назву села російською мовою Федоровка наприкінці XX ст. було передано українською як Федорівка (ураховуючи чергування [о] з [i]). Очевидно, що ойконім Федорівка утворено шляхом топонімійної деривації від імені Федір за допомогою топонімного афікса -івк(а).

Новофедорівка - утворилося в першій половині XIX ст. як поміщицьке село. Назва села складається із 2-х основ (непохідна ново- і похідна федорівк-) та сполучного голосного -о-. У похідній основі федорівк- виділяються корінь федор- та суфікс -івк(а).

20 Мриглод М. Становлення і розвиток моделей ойконімів Правобережної України із християнськими іменами в основах : автореф. дис. ... канд. філол. наук: 10.02.01. Івано-Франківськ, 2002. С. 16.

${ }^{21}$ Історія міст і сіл Української РСР : у 26-ти т. Запорізька область / редкол. т. : В. Петрикін (гол.) та ін. Київ : Головна редакція УРЕ, 1970. Т. 9. С. 221.

22 Мриглод М. Становлення і розвиток моделей ойконімів Правобережної України із християнськими іменами в основах : автореф. дис. ... канд. філол. наук: 10.02.01. Івано-Франківськ, 2002. С. 16. 
Андріїкка - селище Бердянського району Запорізької області, розташоване на річці Кілтиччя, засноване в 1809 р. на місці колишнього татарського аулу Канжегали переселенцями - державними селянами 3 Київщини, Полтавщини та Чернігівщини, а також кріпаками-втікачами. Назва селища походить від першого переселенця 3 Полтавщини Андрія Дерев'янка й утворена за допомогою суфікса $-i \beta \kappa(a)^{23}$.

Нововасилівка - селище міського типу Приазовського району Запорізької області, розташоване у верхів”і річки Апанли (басейн Азовського моря). Засноване в 1823 р. сектантами-молоканами, звідси i походить колишня назва Молоканськ. Ще давніша назва татарського аулу Апанли від річки Апанли. Сучасна назва походить від імені воєводи Василя Істоміна й утворена за допомогою суфікса -івк $(a)^{24}$.

Радивонівка - засноване в 1802 р. Станом на 1886 р. у селі Радивонівка Якимівської волості Мелітопольського повіту Таврійської губернії мешкало 1146 осіб, налічувалось 187 дворів, існували православна церква, школа. Назва походить від українського імені Радивон $^{25}$. У цьому імені спостерігаються деякі цікаві звукові особливості нашої мови: історична зміна давньоукраїнського [i] на [и], а також епентеза [в] між голосними [и] та [о].

Васильківське - засноване в 1927 р. переселенцями із Чернігівської та Сумської областей ${ }^{26}$. Назва походить від зменшувальної форми імені Василь - Василько, із суфіксами -ів- та -ськ-.

Софіївка - село, розташоване в Бердянському районі, на березі p. Буртиччі, засноване на місці ногайського аулу Айтамгали прибулими з Бессарабії болгарами, із с. Шикирликитай (Суворово). Першу назву села російською мовою Софиевка наприкінці XX ст. було передано українською мовою як Софіївка ${ }^{27}$. Ойконім Софї̈вка створено шляхом топонімійної деривації від жіночого імені за допомогою топонімного афікса -ївк(а).

Новософіївка - село у Вільнянському районі Запорізької області, утворилось у 1922 р. Ойконім складається із 2-х основ (непохідна новоі похідна софіївк-) та сполучного голосного -о-. У похідній основі софіївк- виділяються корінь софi-, суфікси -їв- і -к-.

${ }^{23}$ Історія міст і сіл Української РСР : у 26-ти т. Запорізька область / редкол. т. : В. Петрикін (гол.) та ін. Київ : Головна редакція УРЕ, 1970. Т. 9. С. 146.

24 Там само. С. 602.

${ }^{25}$ Там само. С. 704.

${ }^{26}$ Фоменко В. Звідки ця назва? Дніпропетровськ : Промінь, 1969. С. 25.

27 Мриглод М. Становлення і розвиток моделей ойконімів Правобережної України із християнськими іменами в основах : автореф. дис. ... канд. філол. наук: 10.02.01. Івано-Франківськ, 2002. С. 16. 
Малокатеринівка - селище міського типу Запорізької області; засновано в 1775 р.; до 1780 р. - Краснокутівка ${ }^{28}$. Назва виникла способом основоскладання ойконіма Катеринівка й означення Мала (малий - «невеликий розміром, незначний величиною») ${ }^{29}$.

Від таких імен латинського походження, як Антон, Максим, Олексій, Марина та Мар'яна, були утворені такі назви поселень: Антонівка, Максимівка, Олексіївка, Маринівка, Мар'янівка.

Антонівка - село у Вільнянському районі Запорізької області, утворене в 1820-х рр. і назване за ім'ям власника землі Антона Неїжмака. У 1917 р. село увійшло до складу УНР. 20 вересня 1943 р. село визволено Червоною Армією від німецької окупації ${ }^{30}$. Ойконім утворився за допомогою суфікса -івк(a).

Максимівка - засноване в першій половині XIX ст. на території земельних володінь поміщика Максима Дякова. 3 Полтавщини сюди переселились сім'ї кріпаків ${ }^{31}$. Ойконім Максимівка створено шляхом топонімійної деривації від імені Максим за допомогою топонімного афікса -івк(a).

Олексї̈ка - село в Більмацькому районі Запорізької області. Ойконім утворений шляхом топонімійної деривації від імені Олексій за допомогою топонімного афікса -ївк $(a)^{32}$.

Маринівка - село Приморського району, засноване болгарами 3 Бессарабії (с. Банівки) на місці ногайського аулу Кічкіне-Бескекли. Перша назва села російською мовою - Марьина, або Мариино, у радянські часи його було перейменовано на Мариновку. Наприкінці XX ст. iii було передано українською мовою як Маринівка ${ }^{33}$. Ойконім Маринівка створено на основі відповідного імені шляхом топонімійної деривації за допомогою топонімного афікса -івк(a).

Мар'янівка - село в Більмацькому районі Запорізької області. У 1780 р. існувало як колонія Готланд. Згодом, у 1823 р., німцямипереселенцями заснована колонія Кампенау. Засновники - 29 сімей із

${ }^{28}$ Історія міст і сіл Української РСР : у 26-ти т. Запорізька область / редкол. т. : В. Петрикін (гол.) та ін. Київ : Головна редакція УРЕ, 1970. Т. 9. С. 319.

29 Українська мова : енциклопедія / НАН України, Ін-т мовознав. ім. О.О. Потебні, Ін-т укр. мови ; за ред. В. Русанівського та ін. 2-ге вид., випр. і допов. Київ : Вид-во «Українська енциклопедія» ім. М.П. Бажана, 2004. С. 637.

30 Мриглод М. Становлення і розвиток моделей ойконімів Правобережної України із християнськими іменами в основах : автореф. дис. ... канд. філол. наук: 10.02.01. Івано-Франківськ, 2002. С. 18.

${ }^{31}$ Історія міст і сіл Української РСР : у 26-ти т. Запорізька область / редкол. т. :

В. Петрикін (гол.) та ін. Київ : Головна редакція УРЕ, 1970. Т. 9. С. 270.

32 Фоменко В. Звідки ця назва? Дніпропетровськ : Промінь, 1969. С. 72.

${ }_{33}$ Історія міст і сіл Української РСР : у 26-ти т. Запорізька область / редкол. т. : В. Петрикін (гол.) та ін. Київ : Головна редакція УРЕ, 1970. Т. 9. С. 638. 
Західної Пруссії. У 1925-1939 рр. село входило до складу Люксембурзького німецького національного району Маріупольської округи (з 1932 р. - Дніпропетровської області, з 1939 р. - Запорізької області $)^{34}$. Ойконім Мар'янівка утворився за допомогою топонімного афікса -івк (а).

\section{2. Іменні ойконіми єврейського і давньоруського походження}

Меншу групу складають назви поселень, утворені від чоловічих і жіночих імен єврейського та давньоруського походження.

В аналізованому матеріалі імена єврейського походження використано для творення таких ойконімів:

- Яким (Якимівка);

- Мануїл (Мануйлівка);

- Михайло (Михайлівка, Новомихайлівка, Мала Михайлівка);

- Іван (Новоіванівське, Новоіванівка);

- Матвій (Матвіївка);

- Самійло (Самійлівка);

- Яким (Якимівка);

- Ганна (Ганнівка);

- Єлизавета (Слизаветівка).

Якимівка - назва селища міського типу в Запорізькій області ${ }^{35}$, яке було засноване в $1833 \mathrm{p}^{36}$. Ойконім утворено за допомогою суфікса -івк(a) в релятивно посесійній функції від антропоніма Яким, що належав справникові, який керував переселенням жителів із Тамбовської губернії Росії.

Мануйлівка - село Приморського району, засноване на місці ногайського аулу Аргакли болгарськими переселенцями із с. Імпуціта в Бессарабії. Першу назву села російською мовою Манойловка пізніше було змінено на Мануйловку, а наприкінці XX ст. іiї було передано українською мовою як Мануйлівка ${ }^{37}$. У даному разі під час перейменування було змінено первинну основу, що походить від болгарського імені одного з перших мешканців. Очевидно, що ойконім

${ }^{34}$ Історія міст і сіл Української РСР : у 26-ти т. Запорізька область / редкол. т. : В. Петрикін (гол.) та ін. Київ : Головна редакція УРЕ, 1970. Т. 9. С. 409.

35 Українська мова : енциклопедія / НАН України, Ін-т мовознав. ім. О.О. Потебні, Ін-т укр. мови ; за ред. В. Русанівського та ін. 2-ге вид., випр. і допов. Київ : Вид-во «Українська енциклопедія» ім. М.П. Бажана, 2004. С. 745.

${ }^{36}$ Географічна енциклопедія України : у 3-х т. / редкол. : О. Маринич (відп. ред.) та ін. Київ : УРЕ ім. М.П. Бажана, 1993. Т. 3. С. 460.

37 Мриглод М. Становлення і розвиток моделей ойконімів Правобережної України із християнськими іменами в основах : автореф. дис. ... канд. філол. наук: 10.02.01. Івано-Франківськ, 2002. С. 13. 
Мануйлівка створено шляхом топонімійної деривації за допомогою топонімного афікса -івк(а).

Михайлівка - назва селища міського типу в Запорізькій області. Засноване на початку XIX ст. від злиття кількох хуторів, один з яких належав Михайлу Чудновському, нащадку запорізького козака, його іменем і назване поселення. Назва створена за допомогою суфікса івк(а) у релятивно-посесійній функції ${ }^{38}$.

Новомихайлівка - село в Оріхівському районі Запорізької області. Ойконім складається із 2-х основ (непохідна ново- і похідна михайлівк-) та сполучного голосного -о-. У похідній основі михайлівк- виділяються корінь михайл- та суфікс -івк $(a)^{39}$.

Мала Михайлівка - село, засноване в 1879 р. вихідцями 3 Михайлівки Мелітопольського повіту. До 1962 р. мало назву Мала Михайлівка, згодом було перейменоване на честь Білорецького полку, який визволяв територію району від інтервентів і «білих». У 2016 р. повернуто історичну назву.

Новоіванівське - село у Вільнянському районі Запорізької області. Новоіванівське виникло у 20-х рр. минулого століття. У 1932-1933 рр. селяни пережили сталінський геноцид. Із 24 серпня 1991 р. село входить до складу незалежної України ${ }^{40}$. Ойконім складається iз 2-х основ (непохідна ново- і похідна іванівськ-) та сполучного голосного -о-. У похідній основі іванівськ- виділяються корінь іван-, суфікси -ів- і -ськ-.

Новоіванівка - село в Гуляйпільському районі Запорізької області. Ойконім Новоіванівка складається із 2-х основ (непохідна ново- i похідна іванівк-) та сполучного голосного -о-. У похідній основі іванівк- виділяються корінь іван- та суфікс -івк(а).

Матвївка - село у Вільнянському районі Запорізької області. Хутори Матвіївський, Веселий і Шовковий на початку 1918 р. були засновані родинами переселенців із села Вознесенка, які в подальшому сформували село Матвії̈вка. За переказами старожилів, переселення відбувалося і в 1927 р. за ініціативою влади, коли будувалася Дніпровська ГЕС. Переселенці оселилися на землях, які раніше належали німецьким колоністам Класену та Нейфельду ${ }^{41}$. Назву Матвївка дали хутору в пам'ять про рідну вулицю в селі Вознесенка. Ойконім утворений за допомогою суфікса -івк(a).

${ }^{38}$ Фоменко В. Звідки ця назва? Дніпропетровськ : Промінь, 1969. С. 59.

${ }^{39}$ Там само. С. 66.

${ }^{40}$ Історія міст і сіл Української РСР : у 26-ти т. Запорізька область / редкол. т. :

В. Петрикін (гол.) та ін. Київ : Головна редакція УРЕ, 1970. Т. 9. С. 253.

${ }^{41}$ Фоменко В. Звідки ця назва? Дніпропетровськ : Промінь, 1969. С. 56. 
Самійлівка - село в Новомиколаївському районі Запорізької області, яке засноване в 1879 р. переселенцями з Новомиколаївки ${ }^{42}$. Ойконім утворений шляхом топонімійної деривації за допомогою топонімного афікса -івк(a).

Ганнівка - село Приазовського району, розташоване на лівому березі р. Корсак. Воно було засноване на місці ногайського аулу Аргакли болгарами з бессарабського села Карагача (Нагірного). Перша назва села російською мовою Анновка у 90-ті pp. ХХ ст. була передана українською як Ганнівка ${ }^{43}$. Ойконім Ганнівка, що походить від імені Анна (Ганна), утворено шляхом топонімійної деривації за допомогою топонімного афікса -івк(a).

Слизаветівка - цю назву мають три села в Запорізькій області (Василівський, Приморський та Якимівський райони). Ойконім Слизаветівка, що походить від імені Слизавета, утворено шляхом топонімійної деривації за допомогою топонімного афікса -івк(a).

Від імен давньоруського походження були утворені такі ойконіми Запорізької області:

- Богдан (Богданівка);

- В'ячеслав (В'ячеславка);

- Володимир (Володимирівка);

- Надежда (Надеждине).

Богданівка - село у Приазовському районі, на березі річки Корсак, де перед цим було розташовано ногайський аул Асан-Хожа, заселений болгарськими переселенцями 3 бессарабського селища Чешмаваруіта (Криничне). До 90-х рр. ХХ ст. існувала типова для російської мови назва Богдановка, яка після здобуття незалежності Україною набула україномовного звучання та написання як Богданівка (ураховуючи чергування [o] 3 [i] $)^{44}$. Ойконім Богданівка, що походить від імені Богдан, утворено шляхом топонімійної деривації за допомогою топонімного афікса -івк(а).

Володимирівка - село у Вільнянському районі Запорізької області. Воно було створене на початку ХХ ст. як хутір Новогеледжик. У 1917 р. село ввійшло до складу УНР. Унаслідок поразки Перших визвольних змагань село надовго окупували більшовицькі загарбники. Із 24 серпня 1991 р. ввійшло до складу незалежної України ${ }^{45}$. Ойконім

${ }^{42}$ Історія міст і сіл Української РСР : у 26-ти т. Запорізька область / редкол. т. : В. Петрикін (гол.) та ін. Київ : Головна редакція УРЕ, 1970. Т. 9. С. 523.

${ }^{43}$ Там само. С. 615.

44 Мриглод М. Становлення і розвиток моделей ойконімів Правобережної України із християнськими іменами в основах : автореф. дис. ... канд. філол. наук: 10.02.01. Івано-Франківськ, 2002. С. 12.

${ }^{45}$ Фоменко В. Звідки ця назва? Дніпропетровськ : Промінь, 1969. С. 28. 
Володимирівка створено шляхом топонімійної деривації за допомогою топонімного афікса -івк(а).

$B$ 'ячеславка - село, розташоване у Приморському районі, засноване на місці ногайського аулу Ягонда-Шекли болгарами з бессарабського с. Єнікіой (Новоселівка). Названо на честь новонародженого племінника царя В'ячеслава Миколайовича. Перша назва села російською мовою Вячеславовка невдовзі трансформувалася у Вячеславку. У такому вигляді вона функціонувала до 90-х pp. ХХ ст., після чого була передана українською мовою як $B$ 'ячеславка ${ }^{46}$. Ойконім $B$ 'ячеславка утворено від імені $B$ 'ячеслав шляхом топонімійної деривації за допомогою афікса топонімного походження -к(a).

Надеждине - село у Приазовському районі Запорізької області. Першу назву села російською мовою Надежная невдовзі було змінено на Надеждино (за відповідним іменем). Наприкінці XX ст. ця назва була передана українською мовою 3 урахованням національної ідентифікації як Надеждине ${ }^{47}$. Отже, ойконім Надеждине створено шляхом топонімійної деривації від російського імені Надежда за допомогою топонімного афікса -ин(е).

\section{ВИСНОВКИ}

Отже, серед ойконімів Запорізького краю зафіксовано назви, в основу яких покладені імена першопоселенців, власників земельних часток і державних діячів. Відіменні ойконіми утворились здебільшого за допомогою суфіксів -івк(а), -ївк(a), -ів-, -ськ-, префіксів ново-, мало-. Найбільше ойконімів походять від чоловічих і жіночих імен грецького походження - 23 назви, другою за чисельністю $є$ група власних імен єврейського походження - 11, латинське походження мають 5 назв селищ, давньоруське походження - 4 .

Отже, різноманітна ойконімія Запоріжжя може бути джерелом історико-етнографічного вивчення краю за умови комплексного наукового підходу: залучення даних історичної етнографії, мовознавства, усних свідчень місцевих краєзнавців і носіїв народних традицій. Досвід здійсненої нами роботи показав особливе значення сучасної інформації про історію - назв поселень, традицій їхніх мешканців, - яку ще можна отримати від людей старшого віку. Адже в наш час не лише трансформуються самі ойконіми, але й помітно видозмінюється загальна адміністративно-політична карта поселень.

${ }^{46}$ Українська РСР. Адміністративно-територіальний поділ : від 1 січня 1972 р. / упоряд. Д. Шелягін ; відп. ред. В. Кирненко. Київ : Вид-во політичної літератури, 1973. С. 638.

${ }^{47}$ Історія міст і сіл Української РСР : у 26-ти т. Запорізька область / редкол. т. : В. Петрикін (гол.) та ін. Київ : Головна редакція УРЕ, 1970. Т. 9. С. 615. 
Зокрема, загострюється проблема зникнення населених пунктів, які $\epsilon$ досить віддаленими від обласних i районних центрів: менші поселення зливаються 3 більшими, жителі хуторів переселяються в найближчі села, деякі поселення переростають у дачні селища 3 особливою сучасною урбанізованою культурою. Через це стає помітна тенденція збіднення чи втрати історичної пам'яті про знання народу, про те, як він сприймав і розумів традиційну культуру свого поселення.

\section{АНОТАЦІЯ}

У розвідці розглянуто специфіку ойконімів Запорізького краю, проаналізовано їхні семантичні та структурні особливості, а також з'ясовано походження. Актуальність дослідження визначається відсутністю грунтовних наукових досліджень, присвячених структурносемантичним особливостям назв поселень Запорізької області. Теоретично важливим i актуальним видається зв'язок досліджуваної теми iз загальними проблемами української ономастики. Досліджено групу ойконімів, які утворюються від власних назв (антропонімів).

Відантропонімні ойконіми - це назви населених пунктів, походження яких пов'язане з іменами, прізвищами, прізвиськами їхніх власників або мешканців. Найчастіше ойконіми досліджуваної території мотивовані іменами грецького, латинського, єврейського і давньоруського походження. Кожна підгрупа репрезентується різною кількістю прикладів у топонімії досліджуваного регіону. Для відантропонімних ойконімів Запорізького краю характерна наявність специфічних суфіксальних топоформантів, які вказують на приналежність об’єкта певній особі: -ів-, -ськ-, -івк(a), -ївк(a).

\section{ЛІТЕРАТУРА}

1. Ажнюк Б. Переклад і міжмовна ідентифікація власних імен. Академік Олександр Савич Мельничук і сучасне мовознавство : збірник наукових праць. Київ : Видавничий дім Д. Бураго, 2012. С. 228-236.

2. Бажан О. Новомиколаївка. Енциилопедія історії України / редкол. : В. Смолій (голова) та ін. Київ : Наукова думка, 2010. Т. 7. C. 476. URL: http://www.history.org.ua/?termin=Novomykolaivka.

3. Белей Л. Декомунізація топонімії : українські проблеми та європейський досвід. Украӥнський тиждень. 2015. № 16/17. С. 12-15.

4. Беценко T. Етюди 3 топонімії Сумщини. Походження географічних найменувань. Суми : Собор, 2001. С. 55-56.

5. Бондаренко Г. Історична топоніміка : навчальний посібник. Луцьк, 2012. 164 с.

6. Воробйова Л. Лінгвістичні й екстралінгвістичні умови формування українського національного топонімічного фонду й процесу запозичення іншомовної топонімії наприкінці XVII - 
початку XVIII ст. Мовознавчий вісник. 2010. Вип. 11. C. 115-118. URL: http://nbuv.gov.ua/UJRN/Mv_2010_11_27.

7. Географічна енциклопедія України : у 3-х т. / редкол. : О. Маринич (відп. ред.) та ін. Київ : УРЕ ім. М.П. Бажана, 1989. Т. 1. С. 151.

8. Географічна енциклопедія України : у 3-х т. / редкол. : О. Маринич (відп. ред.) та ін. Київ : УРЕ ім. М.П. Бажана, 1993. Т. 3. С. 460.

9. Гнатишин О. Походження топонімів України. Колосок. 2015. № 3. C. 40-43.

10. Горпинич В. Словник географічних назв України (топоніми та відтопонімні прикметники) : близько 25000 слів. Київ : Довіра, $2001.526 \mathrm{c}$.

11. Історія міст і сіл Української РСР : у 26-ти т. Запорізька область / редкол. т. : В. Петрикін (гол.) та ін. Київ : Головна редакція УРЕ, 1970. T. $9.765 \mathrm{c}$.

12. Кордуба М. Що кажуть нам назви осель? Наша Батьківщина. Львів : 1938. № 2. С. 31-37.

13. Лабінська Г. Топоніміка : навчальний посібник. Львів : ЛНУ ім. І. Франка, 2016. 274 с.

14. Лобода В. Вплив антропонімії і гідронімії на творення сучасної ойконімії Північного Причорномор'я. Питання ономастики Південної Украӥни : матеріали V Республіканської ономастичної конференції. Київ, 1974. С. 107-112.

15. Лучик В. Етимологічний словник топонімів України. Київ : ВЦ «Академія», 2014. С. 29-30.

16. Лучик В. Принципи й критерії номінації та відновлення історичних назв у топонімії України. Українська мова. 2009. № 4. C. 28-33.

17. Мороз О. Топоніми в українській мові: когнітивний, прагматичний, конотативний аспекти. Вісник Маріупольського державного університету. Серія «Філологія». 2011. Вип. 5. С. 45-50.

18. Мриглод M. Становлення i розвиток моделей ойконімів Правобережної України із християнськими іменами в основах : автореф. дис. ... канд. філол. наук: 10.02.01. Івано-Франківськ, 2002. 20 с.

19. Пачева В. Ойконіми болгарських сіл Запорізького Надазов'я. Дриновський збірник : збірник наукових праць. Харків ; Софія. 2011. T. 4. C. $549-555$.

20. Скляренко О. Деякі зауваження щодо топонімів відантропонімного походження (типологічний аспект). Слов'янський збірник : збірник наукових праць. Одеса : Одеський національний університет імені I.I. Мечникова, 2012. Вип. 16. С. 220-233.

21. Таранова Н. До питання про класифікацію топонімів. Наукові записки Тернопільського національного педагогічного університету імені Володимира Гнатюка. Серія «Географія». 2015. № 2. С. 15-20. 
22. Українська мова : енциклопедія / НАН України, Ін-т мовознав. ім. О.О. Потебні, Ін-т укр. мови ; за ред. В. Русанівського та ін. 2-ге вид., випр. і допов. Київ : Вид-во «Українська енциклопедія» ім. М.П. Бажана, 2004. С. 183, 637, 745.

23. Українська РСР. Адміністративно-територіальний поділ : від 1 січня 1972 р. / упоряд. Д. Шелягін ; відп. ред. В. Кирненко. Київ : Вид-во політичної літератури, 1973. 815 с.

24. Фоменко В. Звідки ця назва? Дніпропетровськ : Промінь, 1969. $103 \mathrm{c}$.

25. Ханмагомедов Х. Географический фактор в топонимии. Вісник Прикарпатського університету. Серія «Філологія». 2011. № № 29-31. C. 31-35.

26. Худаш M. Походження українських карпатських i прикарпатських назв населених пунктів (відантропонімічні утворення). Київ : Наукова думка, 1991. 266 с.

27. Чабаненко В. Великий Луг Запорозький : історико-топонімічний словник. Запоріжжя : ЗДУ, 1999. $331 \mathrm{c.}$

28. Чорна Н., Швець Г. Особливості функціонування топонімів іспанською мовою. Проблеми семантики, прагматики та когнітивної лінгвістики. 2011. Вип. 19. С. 218-223.

29. Чучка П. Прізвища закарпатських українців : історикоетимологічний словник. Львів : Світ, 2005. 702 с.

30. Шабінський М. Слова кельтського походження в етимології українських та французьких географічних назв. Теоретична $i$ дидактична філологія. 2017. Вип. 25. С. 425-432.

31. Янко М. Топонімічний словник України : словник-довідник. Київ : Знання, 1998. 430 с.

Information about the authors: Ilchenko I. I., Candidate of Philological Sciences, Associate Professor at the Department of Ukrainian Zaporizhzhya National University 66, Zhukovsky str., Zaporizhzhya, 69600, Ukraine

Tkachenko N. V., PhD Student of the Department of Ukrainian Zaporizhzhya National University 66, Zhukovsky str., Zaporizhzhya, 69600, Ukraine 